\title{
Leadership Styles of Principals in Relation to Islamic Teachers' Burnout in Mafraq Education District
}

\author{
Sadeq Hassan Al-Shudaifat ${ }^{1}$ \\ ${ }^{1}$ Faculty of Education, Qatar University, Qatar \\ Correspondence: Sadeq Hassan Al-Shudaifat, Faculty of Education, Qatar University, Qatar. E-mail: \\ salshudaifat@qu.edu.qa
}

Received: March 31, 2015 Accepted: April 30, 2015 Online Published: August 14, 2015

doi:10.5539/res.v7n11p334 URL: http://dx.doi.org/10.5539/res.v7n11p334

\begin{abstract}
The problem investigated in this study is the influence of the leadership styles of principals on burnout as experienced by teachers. A total of 431 teachers from the Mafraq Education District in Jordan answered and returned questionnaires. The Maslach Burnout Inventory and the Administrative Styles Questionnaire were used. The study found no difference in perceptions of principals' leadership styles related to teaching disciplines among the study sample and no difference in burnout scores among Islamic teachers depending on their experience of teaching or school type. There was, however, a difference in Islamic teachers' burnout scores related to their gender. Several recommendations are made for coping with teachers' stress and burnout, contributing to better job performance.
\end{abstract}

Keywords: leadership styles, burnout, teachers of Islamic education, principals

\section{Introduction}

The pressures and challenges inherent in the modern workplace have resulted in a phenomenon called burnout, which affects many of the brightest and most enthusiastic talents in the teaching profession (Briscoe, 1984; Metz, 1979; Moore, 1981; H. Zabel \& K. Zabel, 1982; Zghol, Khrysha \& Khaldi, 2003; Vash, 1980). This phenomenon has received the attention of many researchers because of its negative effects on the human element in the workplace (Cherniss, 1978). Researchers agree that burnout is a negative reaction to occupational stress. Too much stress cripples and sometimes, even kills. (Conoway \& Coleman, 1984).

Makableh and Al Rashdan (1997) define burnout as a drain of the mental energy of the individual, leading him to a state of psychological pressure caused by workload and requirements, the adverse consequences of which are reflected directly on the institution employing the individual. Maslach et al. (1996) suggest that the phenomenon of burnout has three dimensions: emotional exhaustion, depersonalization and lack of personal accomplishment. Lashkar and others (1986) list three important causes of burnout: (a) unrealised expectations and professional ambition, (b) burdens of the career, which cause a sense of frustration for professionals and ever-increasing pressure, and (c) the inability to control factors in the work environment that cause anxiety and stress.

Maslach and Leiter (1997), for their part, recognise six factors that cause burnout. The first is workload; as organizations attempt to maximize productivity, employees feel pressured and pushed to their limits. Second is lack of control; people may lose control over important aspects of their jobs because the organization hinders them in making important decisions, which may lead to a loss of interest in their work. The third factor is insufficient rewards; turbulent economic conditions may cause organizations to withhold material rewards from employees such as extra pay, prestige and security. Moreover, lack of such non-material rewards as performing enjoyable work may lead to burnout. The fourth factor is breakdown of the sense of community, which is an integral part of a healthy work environment and may be undermined by materialistic considerations. Another aspect of community is teamwork, which is an integral feature of work in manufacturing firms and service providers. Thus, when conflict arises between people, burnout takes place. Fifth is the absence of fairness; when people at work perceive unfairness, they are more likely to experience burnout. The final factor is conflicting values, which are common within organizations. For example, values important to the organization itself are efficiency and effectiveness, while the personal values of customers and employees may be overlooked. To avoid stress, all of these conflicting types of values should be handled properly. 
Teaching is one of the professions causing most pressure; it is also among the most stressful environments in the community (Gold \& Roth, 1994). Teachers often develop feelings of disability accompanied by tiredness, leaving them in a state of weariness and psychological exhaustion (Mukablanhand \& Salamah, 1993). These feelings may lead to lack of motivation, resistance to change, loss of ability to invent in teaching and unjustified absence (Asker, Jamea, \& Al-Ansari, 1986), as well as fatigue, irritability, low level of performance at work and low self-esteem (Dwani, Al-Kilani, \& Ulian, 1989; Tawalbeh, 1999; Alimat, 1993; Tahayneh \& Issa, 1996). School management plays a role in increasing or decreasing burnout among teachers (Frase, 1992).

The school director can prevent burnout by changing the level of classes taught by teachers, by giving accurate and positive feedback, by diagnosing problems experienced by teachers and by showing interest in and gratitude for their efforts in order to reduce the sense of isolation that they may experience in school. Maslach and Leiter (1997) claim that the most important factor linked to the negative psychological state of teachers is a lack of support from school administrators. Recent research reveals that managerial stressors are related to ill health, job dissatisfaction, high absenteeism and turnover (Cooper, 1981; Cooper \& Payne, 1978; Davidson \& Cooper, 1983, 1992; Quick et al., 1990). More importantly, they are related to burnout.

With regard to the teaching profession, an analysis of the work, problems and burnout encountered by teachers has led researchers to conclude that teachers are affected by the leadership styles of their principals (Bertrand, 1981; Cherniss, 1980). Most burnout literature suggests that a relationship exists between leadership style and burnout. This connection is validated in the works of Savicki and Cooley (1987) and Boenisch (1983). Hersey and Blanchard (1977) and Fiedler (1967) argue that the dominance of one style depends on the specific situation (situational/contingency leadership), while Blake and Mouton (1978) contend that there is one best form of leadership, normative, which involves a simultaneous high concern for production and concern for people. They identify five major or dominant leadership styles: Caretaker Administration; Comfortable and Pleasant Administration; Authority-Obedience Administration; Team Administration; and Constituency-Centred Administration. These basic styles, which the authors claim are typical of most administrators, are then grouped into two dimensions of leadership: concern for production and concern for people.

Boenisch (1983) found that as a group, student services professionals who rated themselves as having a low concern for people and a low concern for tasks reported high levels of stress. The more integrated the leadership style (concern for people and performance) the lower the level of stress. These findings are important for the present study, since they explore the effect of leadership style on burnout. Zghol, Khrysha and Khaldi (2003) investigated the burnout level among Kerak public high school teachers and its relationship to their perception of the leadership behaviour of their principals. The study found a high degree of burnout on emotional exhaustion and a moderate degree of burnout on depersonalization and lack of personal accomplishment. There were also significant differences in the degree of burnout among teachers due to gender, the highest degree of burnout found among male teachers. The highest degree of burnout was also found to be related to low levels of consideration.

\subsection{Statement of the Problem}

As educators enter the twenty-first century, organizational change continues to be a major source of stress for organization members in terms of work overload, lack of control, insufficient reward, absence of fairness or equity, work-home demands and supervisors' leadership styles. Successful burnout prevention and treatment efforts often require both individual and organizational changes to be effective, rather than one or the other. Individuals must develop effective personal strategies to regain control and reduce their levels of stress. Similarly, organizations must help their employees by using organizational strategies to reduce work stress and ameliorate the effects of burnout in the work environment. The leadership behaviour of principals must be identified and evaluated for its influence on the degree of burnout experienced by teachers. Therefore, this study investigates the influence of the perceived leadership styles of principals on burnout among Islamic teachers in the Mafraq Education District in Jordan.

\subsection{Importance of the Study}

This study is important in that it attempts to identify the effect of the leadership styles of principals on burnout among teachers. Boenisch (1983) suggests that certain leadership styles may be associated with burnout among workers, while Burke (1982) notes that females are at significant risk of developing burnout. Demographic variables identified in the literature are studied to determine their impact on the incidence of burnout experienced by teachers.

This study may add valuable information to the existing literature on burnout among teachers in public educational settings. It may also promote further studies on burnout among public school teachers and identify 
leadership styles that promote individual effectiveness and reduce stress and burnout. It is an attempt to add to the body of knowledge describing the leadership styles of principals and the phenomenon of burnout among teachers of Islamic education. The specific population of this study will be such teachers in public education, whose burnout will affect significantly, the current student body, but also the pool of prospective students, the teachers themselves and the schools. This has national significance in that the culture and economy of Jordan are dependent upon public education for the development and maintenance of educational and cultural standards.

\subsection{Purpose of the Study}

The purpose of this study is to investigate the effects of the leadership styles of principals on burnout among Islamic teachers in the Mafraq education district. The following questions have been formulated to guide the research:

1) How do Islamic teachers perceive their principals' leadership styles?

2) Do Islamic teachers perceive these styles differently from teachers in other disciplines?

3) What is the degree of burnout among Islamic teachers?

4) What effect, if any, do principals' leadership styles, years of experience in teaching, teachers' gender, and school type have upon burnout among Islamic teachers in public schools?

\subsection{Limitations of the Study}

A limitation of this study is that its results are generalized only to those Islamic teachers working in the Mafraq education district in the academic year 2007/2008.

\subsection{Operational Definitions}

The following definitions are used throughout the study.

Leadership styles are behaviours that provide direction and structure for the task and show consideration for the followers' needs (Burke, 1982). Leadership styles in this study are defined operationally as those five basic styles that are measured by the subjects who responded to the Administrative Style Questionnaire (ASQ) in the context of their perceptions of the leadership styles.

Burnout is defined as the subjects' response to the three subscales (Emotional Exhaustion, Depersonalization and Personal Accomplishment) of the Maslach Burnout Inventory (MBI) (Maslach \& Jackson, 1986).

- A high degree of burnout is reflected in high scores on the Emotional Exhaustion (EE) and Depersonalization (DP) subscales and in low scores on the Personal Accomplishment (PA) subscale.

- An average degree of burnout is reflected in average scores on the three subscales.

- A low degree of burnout is reflected in low scores on the EE and DP subscales and in high scores on the PA subscale.

\section{Methodology}

\subsection{Population and Study Sample}

Population for this study is defined as all principals and Islamic teachers in public schools in the Mafraq Education District in Jordan. Ministry of Education sources list 161 Islamic teachers and 2151 other teachers. The sample consisted of all 161 Islamic teachers (65 male and 96 female) and 270 other teachers (130 male and 140 female) selected randomly during the second semester of academic year 2007/ 2008. All 430 subjects returned completed questionnaires.

\subsection{Data Collection Instruments}

\subsubsection{The Administrative Styles Questionnaire}

The ASQ, based on the Managerial Grid concept of Blake and Mouton (1985) and Blake et al. (1981), was used to measure subjects' perceptions of their principals' leadership styles. The Administrator Grid is represented as a grid with concern for production as the $\mathrm{X}$-axis and concern for people as the $\mathrm{Y}$-axis; scores on each axis range from 1 (low) to 9 (high). Blake et al. (1981) specify six basic administrative styles on the Academic Administrator Grid, defined by scores of $(1,1),(9,1),(1,9),(5,5),(9,9)$ and $(9+9)$.

The ASQ was composed of 36 statements, six relating to each of the six styles:

1, 1: Caretaker Administration: Little concern for institutional performance and low involvement in exercising power and authority are typical of this leadership style. Because of a lack of leadership, subordinates' involvement is likely to be low. Questions 2, 12, 13, 24, 28 and 34 are concerned with the designation of this 
style.

9, 1: Authority-Obedience Administration: This leadership style has a high concern for institutional performance and a low concern for people. The major thrust is to get results, exercise power and authority in a unilateral way, and extract obedience from subordinates. Questions 3, 8, 18, 19, 26 and 33 explore this designation.

1, 9: Comfortable and Pleasant Administration: Institutional performance is low and concern for people is high in this orientation. The general belief is that when people are happy, results will take care of themselves and that there will be no need for supervision. Questions 1, 11, 15, 21, 29 and 36 address this designation.

5, 5: Constituency-Centred Administration: The emphasis in this orientation is on moderate institutional performance coupled with moderate concern for people. There is a balance between results and people, so that neither dominates. Leaders adopting this style attempt to gain acceptable results by doing whatever the superior expects and simultaneously avoiding actions that lead to criticism. Questions 4, 19, 17, 20, 30 and 32 are concerned with this designation.

9, 9: Team Administration: This orientation involves integration of concern for institutional performance with simultaneously high concern for people. Subordinates are encouraged to achieve the highest possible performance in terms of quality, quantity and personal satisfaction. Involvement is generated in people who are able to mesh their individual efforts to accomplish meaningful goals that are both sound and creative. Questions $5,9,16,22,27$ and 31 are relevant to this designation.

9+9 Paternalism/ Materialism Administration: This orientation emphasizes a 9, 1 concern for performance coupled with a 1,9 motivated approval giving for compliance. Control of subordinates is maintained by creating a relationship of obligation in such a way as to gain the warmth and affection of subordinates. Questions 6, 7, 14, 23,25 and 35 on the ASQ are concerned with the 9+9 orientation.

The questionnaire used in this study was that used by Al-Omari, Shudaifat and Abu Nabaa (2008) with Cronbach's alpha estimates of reliability coefficients of .85 for Caretaker Administration, .88 for Authority-Obedience, .73 for Comfortable and Pleasant, .87 for Consistency-Centred, .79 for Team and .84 for Paternalism/ Materialism.

\subsubsection{Maslach Burnout Inventory-Educator Survey}

The MBI-Educator Survey (MBI-ES) was used to measure burnout in three areas: emotional exhaustion, depersonalization and personal accomplishment. The EE subscale addresses feelings of being emotionally overextended and exhausted by work. The DP subscale addresses the unfeeling and impersonal response that an individual may exhibit towards a student or client in treatment or instruction. Finally, the PA subscale addresses an individual's feelings of work competence and successful achievement. An individual's response frequency related to each of the subscales is assessed using a seven-point (0 to 6) fully anchored response format. The MBI-ES authors recommend reporting personal accomplishment as actual computations of the item scores rather than as diminished personal accomplishment, as the literature, history of development and consistent use of the MBI have focused on that concept (Maslach et al., 1996).

Burnout is not viewed as a dichotomous variable, but as a continuous one, ranging from low to high degrees of experienced feeling (Maslach et al., 1996, p. 5):

- A high degree of burnout is reflected in high scores on the EE and DP subscales and in low scores on the PA subscale.

- Average scores on the three subscales reflect a moderate degree of burnout.

- A low degree of burnout is shown by low scores on the EE and DP subscales and in high scores on the PA subscale.

Maslach et al. (1996) cite Iwanicki and Schwab's Cronbach's alpha estimates of reliability coefficients of .90 for EE, .76 for DP and .76 for PA on the MBI-ES.

The Arabic version of the questionnaire used in this study was that used by Al-Omari, Shudaifat and Abu Nabaa (2008) with Cronbach's alpha results were .85 for EE, .81 for DP and .78 for PA. The MBI-ES is a twenty-two-item, self-report instrument, with response categories ranging from 0 (= never) to 6 (= every day). Estimated time for respondents to complete the instrument is from 10 to 15 minutes. A scoring key is provided. Individual scores for each of the three subscales are categorized according to the charts provided, indicating a high, average or low degree of burnout in relation to similar professionals, according to norms provided (Maslach et al., 1996). 


\subsection{Design and Data Analysis}

The independent variables in this study were leadership styles (1, 1: Caretaker, 9, 1: Authority-Obedience, 1, 9: Comfortable and Pleasant, 5, 5: Constituency-Centred, 9, 9: Team and 9+9: Paternalism/ Materialism Administration), as measured by the ASQ, and demographic data (years of experience in teaching, teachers' gender and school type).

The dependent variables were the three types of burnout (EE, PA and DP) as measured by the MBI-ES. The SPSS statistical package was used to analyze the research data.

\section{Results}

\subsection{How do Islamic Teachers Perceive Their Principals'Leadership Styles?}

Table 1 presents means and standard deviation (SD) results that indicate most Islamic teachers perceived their principals' leadership style as Caretaker, with a mean of 21.48 .

Table 1. Means and standard deviation for perceived leadership styles

\begin{tabular}{lll}
\hline Leadership style & Mean & SD \\
\hline$(1,1)$ Caretaker Administration & 21.48 & 5.188 \\
$(1,9)$ Comfortable and Pleasant Administration & 20.32 & 4.192 \\
$(5,5)$ Constituency-Centred Administration & 20.37 & 4.638 \\
$(9,1)$ Authority-Obedience Administration & 20.60 & 5.086 \\
$(9,9)$ Team Administration & 20.81 & 4.813 \\
$(9+9)$ Paternalism/ Materialism Administration & 20.46 & 4.165 \\
\hline
\end{tabular}

\subsection{Do Islamic Teachers Perceive Their Principals' Leadership Styles Differently from Other Teachers?}

T-test results, means and SDs for the responses of teachers of Islamic Education and of other disciplines are shown in Table 2. These indicate no differences between the two groups in perception of their principals' leadership styles.

Table 2. T-test, Means and SDs for perceived leadership styles by discipline

\begin{tabular}{llllllll}
\hline Leadership styles & Position & Mean & S.D. & N & T & df & sig \\
\hline Caretaker Administration & Islamic teachers & 21.48 & 5.188 & 161 & -1.573 & 429 & .116 \\
& Other teachers & 22.26 & 4.834 & 270 & & & \\
Comfortable and Pleasant & Islamic teachers & 20.32 & 4.192 & 161 & -.365 & 429 & .715 \\
Administration & Other teachers & 20.47 & 3.974 & 270 & & & \\
Constituency-Centred & Islamic teachers & 20.37 & 4.638 & 161 & -.243 & 429 & .808 \\
Administration & Other teachers & 20.48 & 4.148 & 270 & & & \\
Authority-Obedience & Islamic teachers & 20.60 & 5.086 & 161 & -1.221 & 429 & .223 \\
Administration & Other teachers & 21.20 & 4.758 & 270 & & & \\
Team Administration & Islamic teachers & 20.81 & 4.813 & 161 & -.973 & 429 & .331 \\
& Other teachers & 21.24 & 4.260 & 270 & & & \\
Paternalism/ Materialism & Islamic teachers & 20.46 & 4.165 & 161 & -.074 & 429 & .941 \\
Administration & Other teachers & 20.49 & 3.836 & 270 & & & \\
\hline
\end{tabular}

\subsection{What Is the Degree of Burnout among Islamic Teachers?}

To assess the degree of burnout among Islamic teachers, means and SDs were computed. The numerical cut-off points are shown in Table 3, adapted from Maslach et al. $(1996$, p. 6). The results indicate a high degree of 
burnout, reflected in high means on the $\mathrm{EE}(\mathrm{M}=36.05)$ and $\mathrm{DP}(\mathrm{M}=15.24)$ subscales and in average means on the PA subscale $(\mathrm{M}=33.42)$.

Table 3. Degree of burnout among Islamic teachers-Means and SDs

\begin{tabular}{llll}
\hline \multirow{2}{*}{ MBI Subscales } & Degree & Mean Range & Means \& SDs for this study \\
\hline Emotional Exhaustion & Low & $\leq 16$ & $\mathrm{M}=36.05$ \\
& Average & $17-26$ & $\mathrm{SD}=(11.29)$ \\
& High & $\geq 27$ & \\
Depersonalization & Low & $\leq 6$ & $\mathrm{M}=15.24$ \\
& Average & $7-12$ & $\mathrm{SD}=(6.11)$ \\
\multirow{3}{*}{ Personal Accomplishment } & High & $\geq 13$ & \\
& Low & $\geq 39$ & $\mathrm{M}=33.42$ \\
& Average & $32-38$ & $\mathrm{SD}=(8.18)$ \\
& High & $\leq 31$ & \\
\hline
\end{tabular}

3.4 What Effect do Principals'Leadership Styles, Years of Experience in Teaching, Teachers' Gender and School Type Have upon Islamic Teachers' Burnout?

A four-way multivariate analysis of variance (MANOVA) was used to test the effect on Islamic teachers' burnout of their principals' leadership styles as teachers perceived them, of their length of experience in teaching, their gender and school type. Results are given in Table 4.

Table 4. Four-way MANOVA of difference in teachers' burnout scores due to principals' perceived leadership styles, years of experience in teaching, gender and school type

\begin{tabular}{llllll}
\hline Effect & \multicolumn{2}{l}{ Wilks' Lambda Value F } & Hypothesis df & Error df & Sig. \\
\hline Principals' leadership styles & .002 & 34.74 & 174.00 & 927.33 & .07 \\
Experience in teaching & .263 & 97.76 & 6.00 & 618.00 & .12 \\
Teachers' gender & .805 & 24.947 & 3.00 & 309.00 & $.00^{*}$ \\
School type & .799 & 25.947 & 3.00 & 309.00 & .08 \\
\hline
\end{tabular}

$*<.05$

No difference was found in burnout scores for perceived leadership styles, respondents' experience in teaching, or for school type, but Table 4 indicates that there was a difference in burnout scores according to teachers' gender. The omnibus $F$ Test was statistically significant $(F=7.781 ; \mathrm{df}=6 ; \mathrm{p}<.00)$.

A univariate analysis was conducted as a follow-up test to assess the effect of Islamic teachers' gender on the burnout variables (EE, DP and PA). ANOVA results are given in Table 5, while Table 6 indicates that teachers' burnout scores on depersonalization were significantly higher for female $(M=16.893)$ than male respondents $(\mathrm{M}=13.967)$. 
Table 5. ANOVA summary of burnout scores by teacher gender

\begin{tabular}{|c|c|c|c|c|c|c|}
\hline Source & Dependent Variable & $\begin{array}{l}\text { Type III } \\
\text { Squares }\end{array}$ & ofDf & Mean Square & $\mathrm{F}$ & Sig. \\
\hline \multirow{3}{*}{$\begin{array}{l}\text { Teacher's } \\
\text { gender }\end{array}$} & Emotional Exhaustion & 33.709 & 1 & 33.709 & 2.13 & .145 \\
\hline & Depersonalization & 139.276 & 1 & 139.276 & 56.081 & $.001 *$ \\
\hline & $\begin{array}{l}\text { Personal } \\
\text { Accomplishment }\end{array}$ & .0096 & 1 & .0096 & .026 & .872 \\
\hline
\end{tabular}

$*<.05$

Table 6. Means and SDs for Islamic teachers' gender on depersonalization

\begin{tabular}{lllll}
\hline & Gender & Mean & Std. Deviation & N \\
\hline Depersonalization & Male & 13.967 & .105 & 65 \\
& Female & 16.893 & .116 & 130 \\
\hline
\end{tabular}

\section{Discussion and Recommendations}

The negative consequences of stress and burnout have received extensive attention in recent years. Burned out employees are less productive, less energetic and less interested in their jobs. They are fatigued, depressed, irritable and bored. The direct and indirect costs of burnout to organizations include absenteeism, lower productivity, accidents, turnover and poor quality work (Lee \& Ashforth, 1991). In 1990, the cost of workers' compensation related to workplace stress claims was estimated at $\$ 60$ billion (Hasty, 1991).

The economic, social and ethical ramifications for organizations regarding stress and burnout cannot be overemphasized. In order to alleviate the negative consequences of workplace stress and its ultimate manifestation, burnout, managers need to play a more central role in helping employees to achieve higher performance levels. There is a need for intervention at the organizational level. Efforts should be directed at humanizing the work climate in order to maximize employee performance and minimize the negative aspects of job stress and burnout.

The analyses of the results of this study fail to identify specific leadership styles that lead to burnout, which agrees with Bertrand (1981) and Cherniss (1980). No differences were found between Islamic teachers and those from other disciplines in the way that they perceived their principals' leadership styles.

The results of this study indicate that Islamic teachers suffer a high degree of burnout, reflected in high means on the Emotional Exhaustion and Depersonalization subscales and in average means on the Personal Accomplishment subscale, which agrees with studies by Scott (1978), Vash (1980), Austin and Gamson (1983), Scott (1978) and Kanter (1979).

The results also indicate that female teachers had higher depersonalization scores than males, in contrast to Zghol et al. (2003), who found a higher level of burnout among male teachers, and Tawalbeh (1999) who found no statistically significant differences in burnout level attributed to teachers' gender. Teachers may be at greater risk of depersonalization because their daily working life often includes large periods of isolation from their professional peers. While teachers do interact with others on a regular basis throughout the workday, the majority of such interactions are with students, not with other teachers or professional staff members who might better understand the demands they face.

No significance difference in teachers' burnout scores was found to correlate with their experience in teaching, which differs from the results, reported by Askar et al. (1986). The present study also found no difference in Islamic teachers' burnout scores by school type, whereas Askar et al. (1986) report a relatively low degree of burnout among secondary school teachers.

Burnout is the result of a long period of stress and from the perception of a teacher that the resources available to deal with the stress are not adequate. In other words, the stressors (demands of the job) outweigh the resources available to deal with them. For example, a teacher must face a classroom full of students every day, negotiate potentially stressful interactions with parents, administrators, counsellors and other teachers, and ensure that the students meet increasingly strict standards of accountability (Wood \& McCarthy, 2000). 
Prevention of teachers' burnout may come from organizational practices that allow teachers some control over their daily challenges. At the individual level, self-efficacy and the ability to maintain perspective with regard to daily events have been described as "anxiety-buffers" (Greenberg, 1999). At the institutional level, other factors may help mitigate teacher stress. Kyriacou (2001) offers the following advice for schools: Consult with teachers on matters such as curriculum development or instructional planning, which directly affect their classrooms. Provide adequate resources and facilities to support teachers in instructional practice. Provide clear job descriptions and expectations in an effort to address role ambiguity and conflict. Establish and maintain open lines of communication between teachers and administrators to provide administrative support and performance feedback, which may act as a buffer against stress. Allow for and encourage professional development activities such as mentoring and networking, which may engender a sense of accomplishment and a more fully developed professional identity for teachers.

Based upon the findings and the conclusions of this study, the following recommendations are made. Attention should be given to the lack of difference observed in this study between leadership styles as perceived by Islamic teachers and other teachers with whom they work closely. This study should be replicated with a broader group of Islamic teachers and principals to explore whether differences can be identified in the variables under study. Training programmes should be developed to teach administrative strategies for coping with stress and burnout. Teachers who do not have any source of support available to them will become less effective in their classroom instruction and in relationships with students and other teachers. Schools could lose valuable resources if teachers leave the profession. The cost of a stress reduction programme is low compared to the loss of an experienced employee.

\section{References}

Alimat, M. (1993). A prospective study of the phenomenon of burnout in teachers of secondary vocational education in the governorate of Irbid, after the variables of experience, qualifications, gender and profession. Journal of faculty of Education, University of Mustansiriya, 2, 215-237.

Al-Omari, A., Shudaifat, S., \& Abu Nabaa, A. (2008). The effect of leadership styles of principals on teachers' burnout at Russaifa education directorate in Jordan. Journal of Educational Sciences, 4(1), 63-78.

Askar, A., Jamea, H., \& Al-Ansari, M. (1986). The extent of burnout among secondary school teachers in the State of Kuwait. Educational Journal, 3(10), 9-43.

Austin, A. E., \& Gamson, Z. F. (1983). Academic workplace: New demands, heightened tensions (Report No. 10). Washington, D.C.: Association for the Study of Higher Education.

Bertrand, U. S. (1981). Personal and organizational correlates of role stress and job satisfaction in female managers. Doctoral dissertation, University of Wisconsin. Dissertation Abstracts International, 42, 1051A.

Blake, R. R., \& Mouton, J. S. (1978). Should you teach there's only one best way to manage? Training, 15(4), 24-27.

Blake, R. R., \& Mouton, J. S. (1985). The managerial grid III (3rd ed.). Houston: Gulf.

Blake, R. R., Mouton, J. S., \& Williams, M. S. (1981). The academic administrator grid. San Francisco: Jossey-Bass.

Boenisch, E. W. Jr. (1983). Leadership style: Job type, stress, and satisfaction among community college student personnel professional. Doctoral dissertation, University of Northern Colorado. Dissertation Abstracts International, 44, 2336A.

Briscoe, M. L. (1984). Reflections on academic burnout. Association of Departments of English Bulletin, 79, 1-7. http://dx.doi.org/10.1632/ade.79.1

Burke, W. W. (1982). Organization development: Principles and practices. Boston: Little, Brown.

Cherniss, C. (1980). Professional burnout in human service organization. New York: Praeger Press.

Conaway, B., \& Coleman, A. P. (1984). Burnout and school administrators: A review of literature. Small School Forum, 6(1), 1-3.

Cooper, C. L. (1981). The Stress Check: Coping with the Stresses of Life and Work. Englewood Cliffs: Prentice-Hall.

Cooper, C. L., \& Payne, R. (Eds.). (1978). Stress at Work. Chichester: Wiley.

Davidson, M., \& Cooper, C. L. (1983). Stress and the Woman Manager. Oxford: Martin Robertson. 
Davidson, M., \& Cooper, C. L. (1992). The Woman Manager. London: Chapman.

Dwani, K., Al-Kilani, A., \& Ulian, K. (1989). Levels of Teacher Burnout in Jordan, 19(5), 253-273.

Fiedler, F. E. (1967). A theory of leadership effectiveness. New York: McGraw-Hill.

Gold, Y., \& Roth, R. (1994). Teachers Managing Stress and Preventing Burnout: the Professional Health Solution (2nd ed.). London: Falmer.

Greenberg, J. S. (1999). Comprehensive stress management (6th ed.). Boston: McGraw-Hill.

Hasty, K. N. (1991). Workers' compensation: Will college and university professors be compensated for mental injuries caused by work-related stress? Journal of College and University Law, 17(4), 535-549.

Hersey, P., \& Blanchard, K. (1977). Management of organizational behavior: Utilizing human resources (3rd ed.). Englewood Cliffs, NJ: Prentice-Hall.

Kanter, R. M. (1979). Changing the shape of work: Reform in academe (Report No. 7). Washington, D.C.: American Association for Higher Education.

Kyriacou, C. (2001). Teacher stress: Directions for future research. Educational Review, 53(1), 28-35. http://dx.doi.org/10.1080/00131910120033628

Lee, R. T., \& Ashforth, B. E. (1991). Work-unit structure and processes and job-related stressors as predictors of managerial burnout. Journal of Applied Social Psychology, 21, 1831-1847. http://dx.doi.org/10.1111/j.1559-1816.1991.tb00507.x

Makableh, N., \& Al Rashdan, M. (1997). Burnout among members of the teaching staff in Jordanian universities, governmental organizations and its relationship to some variables. Yarmouk Researchers, 13(2), 37-56.

Maslach, C., \& Jackson, S. E. (1986). Maslach burnout inventory manual (2nd ed.). Palo Alto, CA: Consulting Psychologists Press.

Maslach, C., \& Leiter, M. (1997). The truth about burnout: How organizations cause personal stress and what to do about it. San Francisco: Jossey-Bass.

Maslach, C., Jackson, S. E., \& Leiter, M. P. (1996). Maslach burnout inventory manual (3rd ed.). Palo Alto, Calif.: Consulting Psychologists Press.

Metz, P. K. (1979). An exploratory study of professional burnout and renewal among educators. Doctoral dissertation, University of Colorado at Boulder. Dissertation Abstracts International, 40, 4308A.

Moore, B. L. (1981). Differences in burnout among principals within categories of demographic variables. Doctoral dissertation, Bowling Green State University. Dissertation Abstracts International, 41, 4239A.

Mukablah, N., \& Salamah, K. (1993). The Burnout Phenomenon among Public school Teachers in Jordan. Damascus University Journal, 9(33-34), 179-213.

Quick, J. C., Nelson, D., \& Quick, J. D. (1990). Stress and Challenge at the Top. Chichester: Wiley.

Savicki, V., \& Cooley, E. (1987). The relationship of work environment and client contact to burnout in mental health professionals. Journal of Counselling and Development, 65, 249-252. http://dx.doi.org/10.1002/j.1556-6676.1987.tb01276.x

Scott, R. A. (1978). Lords, squires and yeomen: Collegiate middle managers and their organizations (Report No. 7). Washington, D.C.: American Association for Higher Education.

Tahayneh, Z., \& Issa, S. (1996). Levels of Burnout among Physical Education Teachers in Jordan and their Relation with some Variables. Dirasat, 23(1), 131-148.

Tawalbeh, M. (1999). Burnout levels among computer teachers in schools of Irbid, Mafraq, Ajloun, and Jerash Governorates. Mu'tah Journal for Research and Studies, 14(2), 169-195.

Vash, C. L. (1980). The burnout administrator. New York: Springer.

Wood, T., \& McCarthy, C. (2000). Understanding and Preventing Teacher Burnout. Washington DC: ERIC Clearinghouse on Teaching and Teacher Education.

Zabel, R. H., \& Zabel, M. K. (1982). Burnout: A critical issue for educators. Education Unlimited, 2(2), $23-25$.

Zghol, R., Khrysha, M., \& Khaldi, M. (2003). Burnout among teachers and its relation to their perception of principals' leadership styles at public Kerak high school. Mu'tah Journal for Research and Studies, 18(6), 243-268. 


\section{Appendix A}

\section{Administrative Styles Questionnaire}

\section{Self Assessment}

Six areas of leadership are identified in this questionnaire. In each area are statements, which describe various styles of leadership. Please read all of the statements and then rank each statement from 1-6 with:

6 being your preferred style,

5 being your second most preferred style,

4 being your third most preferred style,

3 being your fourth most preferred style,

2 being your fifth most preferred style, and

1 being your least preferred leadership style.

Each statement must be ranked differently. There can be no duplicate ranks.

\begin{tabular}{|c|c|c|c|c|c|c|c|}
\hline 1 & I initiate actions that help and support others. & 6 & 5 & 4 & 3 & 2 & 1 \\
\hline 2 & I put out enough to get by. & 6 & 5 & 4 & 3 & 2 & 1 \\
\hline 3 & I drive myself and others. & 6 & 5 & 4 & 3 & 2 & 1 \\
\hline 4 & I seek to maintain a steady pace. & 6 & 5 & 4 & 3 & 2 & 1 \\
\hline 5 & I exert vigorous effort and cause others to join in enthusiastically. & 6 & 5 & 4 & 3 & 2 & 1 \\
\hline 6 & I stress loyalty and extend appreciation to those who support his/ her initiatives. & 6 & 5 & 4 & 3 & 2 & 1 \\
\hline 7 & $\begin{array}{l}\text { I double-check what others tell him/ her and compliment them when I am able } \\
\text { to verify their position }\end{array}$ & 6 & 5 & 4 & 3 & 2 & 1 \\
\hline 8 & $\begin{array}{l}\text { I investigate the facts and positions so that he/ she is in control of any situation } \\
\text { and to assure that others are not making mistakes. }\end{array}$ & 6 & 5 & 4 & 3 & 2 & 1 \\
\hline 9 & $\begin{array}{l}\text { I invite and listen for opinions and ideas different from my own. Continuously } \\
\text { re-evaluates his/ her facts, beliefs, and positions. }\end{array}$ & 6 & 5 & 4 & 3 & 2 & 1 \\
\hline 10 & $\begin{array}{l}\text { I take things at face value and check facts and positions when obvious } \\
\text { discrepancies appear. }\end{array}$ & 6 & 5 & 4 & 3 & 2 & 1 \\
\hline 11 & $\begin{array}{l}\text { I look for facts and positions that suggest all is well. Prefer harmony to } \\
\text { challenge. }\end{array}$ & 6 & 5 & 4 & 3 & 2 & 1 \\
\hline 12 & I go along with facts and opinions given him. & 6 & 5 & 4 & 3 & 2 & 1 \\
\hline 13 & $\begin{array}{l}\text { I keep my own position and avoid taking sides by revealing true opinions or } \\
\text { ideas. }\end{array}$ & 6 & 5 & 4 & 3 & 2 & 1 \\
\hline 14 & $\begin{array}{l}\text { I maintain strong convictions but permit others to express their ideas so that I } \\
\text { can help them think more objectively. }\end{array}$ & 6 & 5 & 4 & 3 & 2 & 1 \\
\hline 15 & I take the opinions and ideas of others even though I may have reservations. & 6 & 5 & 4 & 3 & 2 & 1 \\
\hline 16 & $\begin{array}{l}\text { I feel it is important to express his/ her convictions and respond to sound ideas } \\
\text { by changing my mind. }\end{array}$ & 6 & 5 & 4 & 3 & 2 & 1 \\
\hline 17 & I express opinions and ideas in a tentative way and try to meet others halfway. & 6 & 5 & 4 & 3 & 2 & 1 \\
\hline 18 & $\begin{array}{l}\text { I stand up for my opinions and ideas even though it means rejecting the views of } \\
\text { others. }\end{array}$ & 6 & 5 & 4 & 3 & 2 & 1 \\
\hline 19 & I try to cut it off or win my position. & 6 & 5 & 4 & 3 & 2 & 1 \\
\hline 20 & I try to find a position that others find suitable. & 6 & 5 & 4 & 3 & 2 & 1 \\
\hline 21 & I try to soothe feelings to keep people together. & 6 & 5 & 4 & 3 & 2 & 1 \\
\hline 22 & I seek reasons for it in order to resolve the underlying causes. & 6 & 5 & 4 & 3 & 2 & 1 \\
\hline
\end{tabular}




\begin{tabular}{|c|c|c|c|c|c|c|c|}
\hline 23 & I terminate it but thank people for expressing their views. & 6 & 5 & 4 & 3 & 2 & 1 \\
\hline 24 & I remain neutral or seek to stay out of conflict. & 6 & 5 & 4 & 3 & 2 & 1 \\
\hline 25 & $\begin{array}{l}\text { I have the last say and make a sincere effort to see that his/ her decisions are } \\
\text { accepted. }\end{array}$ & 6 & 5 & 4 & 3 & 2 & 1 \\
\hline 26 & $\begin{array}{l}\text { I place a high value on making my own decisions and rarely is influenced by } \\
\text { others. }\end{array}$ & 6 & 5 & 4 & 3 & 2 & 1 \\
\hline 27 & $\begin{array}{l}\text { I place a high value on arriving at sound decisions based on understanding and } \\
\text { agreement. }\end{array}$ & 6 & 5 & 4 & 3 & 2 & 1 \\
\hline 28 & I allow others to make decisions or come to terms with whatever happens. & 6 & 5 & 4 & 3 & 2 & 1 \\
\hline 29 & $\begin{array}{l}\text { I look for decisions that maintain good relations and encourage others to make } \\
\text { decisions. }\end{array}$ & 6 & 5 & 4 & 3 & 2 & 1 \\
\hline 30 & I search for workable decisions that others will accept. & 6 & 5 & 4 & 3 & 2 & 1 \\
\hline 31 & I encourage two-way feedback to strengthen operations. & 6 & 5 & 4 & 3 & 2 & 1 \\
\hline 32 & I give informal feedback regarding suggestions for improvement. & 6 & 5 & 4 & 3 & 2 & 1 \\
\hline 33 & I identify weaknesses in my staff. & 6 & 5 & 4 & 3 & 2 & 1 \\
\hline 34 & I avoid giving feedback. & 6 & 5 & 4 & 3 & 2 & 1 \\
\hline 35 & $\begin{array}{l}\text { I give others feedback and expect them to accept it because it is for their own } \\
\text { good. }\end{array}$ & 6 & 5 & 4 & 3 & 2 & 1 \\
\hline 36 & $\begin{array}{l}\text { I encourage and praise when something positive happens, but avoids giving } \\
\text { negative comments. }\end{array}$ & 6 & 5 & 4 & 3 & 2 & 1 \\
\hline
\end{tabular}

\section{Appendix B}

\section{Administrative Styles Questionnaire Staff Assessment}

Six areas of leadership are identified in this questionnaire. In each area are statements, which describe various styles of leadership. Please read all of the statements and then rank each statement as to how you perceive your immediate administrative supervisor. Rank each statement on a scale from 1-6 with:

6 being your perception of your administrator's most frequently observed style,

5 being his/ her second most frequently observed style,

4 being his/ her third most frequently observed style,

3 being his/ her fourth most frequently observed style,

2 being his/ her fifth most frequently observed style, and

1 being his/ her least observed leadership style.

Each statement must be ranked differently. There can be no duplicate ranks. 


\begin{tabular}{|c|c|c|c|c|c|c|c|}
\hline 1 & My Administrator initiates actions that help and support others. & 6 & 5 & 4 & 3 & 2 & 1 \\
\hline 2 & My Administrator puts out enough to get by. & 6 & 5 & 4 & 3 & 2 & 1 \\
\hline 3 & My Administrator drives himself and others. & 6 & 5 & 4 & 3 & 2 & 1 \\
\hline 4 & My Administrator seeks to maintain a steady pace. & 6 & 5 & 4 & 3 & 2 & 1 \\
\hline 5 & $\begin{array}{l}\text { My Administrator exerts vigorous effort and causes others to join in } \\
\text { enthusiastically. }\end{array}$ & 6 & 5 & 4 & 3 & 2 & 1 \\
\hline 6 & $\begin{array}{l}\text { My Administrator stresses loyalty and extends appreciation to those who support } \\
\text { his/ her initiatives. }\end{array}$ & 6 & 5 & 4 & 3 & 2 & 1 \\
\hline 7 & $\begin{array}{l}\text { My Administrator double-checks what others tell him/ her and compliments them } \\
\text { when he/ she is able to verify their position. }\end{array}$ & 6 & 5 & 4 & 3 & 2 & 1 \\
\hline 8 & $\begin{array}{l}\text { My Administrator investigates the facts and positions so that he/ she is in control } \\
\text { of any situations and to assure that others are not making mistakes. }\end{array}$ & 6 & 5 & 4 & 3 & 2 & 1 \\
\hline 9 & $\begin{array}{l}\text { My Administrator invites and listens for opinions and ideas different from his/ her } \\
\text { own. Continuously re-evaluates his/ her facts, beliefs, and positions. }\end{array}$ & 6 & 5 & 4 & 3 & 2 & 1 \\
\hline 10 & $\begin{array}{l}\text { My Administrator takes things at face value and checks facts and positions when } \\
\text { obvious discrepancies appear. }\end{array}$ & 6 & 5 & 4 & 3 & 2 & 1 \\
\hline 11 & $\begin{array}{l}\text { My Administrator looks for facts and positions that suggest all is well. Prefers } \\
\text { harmony to challenge. }\end{array}$ & 6 & 5 & 4 & 3 & 2 & 1 \\
\hline 12 & My Administrator goes along with facts and opinions given him. & 6 & 5 & 4 & 3 & 2 & 1 \\
\hline 13 & $\begin{array}{l}\text { My Administrator keeps his own position and avoids taking sides by revealing } \\
\text { true opinions or ideas. }\end{array}$ & 6 & 5 & 4 & 3 & 2 & 1 \\
\hline 14 & $\begin{array}{l}\text { My Administrator maintains strong convictions but permits others to express their } \\
\text { ideas so that he/ she can help them think more objectively. }\end{array}$ & 6 & 5 & 4 & 3 & 2 & 1 \\
\hline 15 & $\begin{array}{l}\text { My Administrator takes the opinions and ideas of others even though he/ she may } \\
\text { have reservations. }\end{array}$ & 6 & 5 & 4 & 3 & 2 & 1 \\
\hline 16 & $\begin{array}{l}\text { My Administrator feels it is important to express his/ her convictions and respond } \\
\text { to sound ideas by changing his/ her mind }\end{array}$ & 6 & 5 & 4 & 3 & 2 & 1 \\
\hline 17 & $\begin{array}{l}\text { My Administrator expresses opinions and ideas in a tentative way and tries to } \\
\text { meet others halfway. }\end{array}$ & 6 & 5 & 4 & 3 & 2 & 1 \\
\hline 18 & $\begin{array}{l}\text { My Administrator stands up for his/ her opinions and ideas even though it means } \\
\text { rejecting the views of others. }\end{array}$ & 6 & 5 & 4 & 3 & 2 & 1 \\
\hline 19 & My Administrator tries to cut it off or win his/ her position. & 6 & 5 & 4 & 3 & 2 & 1 \\
\hline 20 & My Administrator tries to find a position that others find suitable. & 6 & 5 & 4 & 3 & 2 & 1 \\
\hline 21 & My Administrator tries to soothe feelings to keep people together. & 6 & 5 & 4 & 3 & 2 & 1 \\
\hline 22 & My Administrator seeks reasons for it in order to resolve the underlying causes. & 6 & 5 & 4 & 3 & 2 & 1 \\
\hline 23 & My Administrator terminates it but thank people for expressing their views. & 6 & 5 & 4 & 3 & 2 & 1 \\
\hline 24 & My Administrator remains neutral or seeks to stay out of conflict. & 6 & 5 & 4 & 3 & 2 & 1 \\
\hline 25 & $\begin{array}{l}\text { My Administrator has the last say and makes a sincere effort to see that his/ her } \\
\text { decisions are accepted. }\end{array}$ & 6 & 5 & 4 & 3 & 2 & 1 \\
\hline 26 & $\begin{array}{l}\text { My Administrator places a high value on making his/ her own decisions and } \\
\text { rarely is influenced by others. }\end{array}$ & 6 & 5 & 4 & 3 & 2 & 1 \\
\hline 27 & $\begin{array}{l}\text { My Administrator places a high value on arriving at sound decisions based on } \\
\text { understanding and agreement. }\end{array}$ & 6 & 5 & 4 & 3 & 2 & 1 \\
\hline 28 & $\begin{array}{l}\text { My Administrator allows others to make decisions or come to terms with } \\
\text { whatever happens. }\end{array}$ & 6 & 5 & 4 & 3 & 2 & 1 \\
\hline
\end{tabular}




\begin{tabular}{|l|l|l|l|l|l|l|l|}
\hline 29 & $\begin{array}{l}\text { My Administrator looks for decisions that maintain good relations and encourages } \\
\text { others to make decisions. }\end{array}$ & 5 & 4 & 3 & 2 & 1 \\
\hline 30 & My Administrator searches for workable decisions that others will accept. & 6 & 5 & 4 & 3 & 2 & 1 \\
\hline 31 & My Administrator encourages tow-way feedback to strengthen operations. & 6 & 5 & 4 & 3 & 2 & 1 \\
\hline 32 & $\begin{array}{l}\text { My Administrator gains informal feedback regarding suggestions for } \\
\text { improvement. }\end{array}$ & 6 & 5 & 4 & 3 & 2 & 1 \\
\hline 33 & My Administrator identifies weaknesses in his/ her staff. & 6 & 5 & 4 & 3 & 2 & 1 \\
\hline 34 & My Administrator avoids giving feedback. & 6 & 5 & 4 & 3 & 2 & 1 \\
\hline 35 & $\begin{array}{l}\text { My Administrator gives others feedback and expects them to accept it because it } \\
\text { is for their own good. }\end{array}$ & 6 & 5 & 3 & 2 & 1 \\
\hline 36 & $\begin{array}{l}\text { My Administrator encourages and praises when something positive happens, but } \\
\text { avoids giving negative comments. }\end{array}$ & 6 & 4 & 3 & 2 \\
\hline
\end{tabular}

\section{Appendix C}

\section{Maslach Burnout Inventory}

Instructions: This section tries to discover how teachers view their job and the people with whom they work closely. The statements presented are about job-related feelings. Please read each statement carefully and decide if you ever feel this way about your job. If you have never had this feeling, circle " 0 " (zero) on the rating scale. If you have had the feeling presented, indicate how often you feel it; circle a number from 1 to 6 on the scale that best describes how frequently you feel that way. Please answer every statement.

0 Never

1 A few times a year or less

2 Once a month

3 A few times a month or less

4 Once a week

5 A few times a week

6 Every day

\begin{tabular}{|c|c|c|c|c|c|c|c|c|}
\hline & Items & & & & & & & \\
\hline 1 & I feel emotionally drained because of my work & 0 & 1 & 2 & 3 & 4 & 5 & 6 \\
\hline 2 & I feel used up at the end of the workday & 0 & 1 & 2 & 3 & 4 & 5 & 6 \\
\hline 3 & $\begin{array}{l}\text { I feel fatigued when I get up in the morning and have to face another day on } \\
\text { the job }\end{array}$ & 0 & 1 & 2 & 3 & 4 & 5 & 6 \\
\hline 4 & I can easily understand how other employees feel about things & 0 & 1 & 2 & 3 & 4 & 5 & 6 \\
\hline 5 & I feel I treat some employees as if they were impersonal objects & 0 & 1 & 2 & 3 & 4 & 5 & 6 \\
\hline 6 & Working with people all day is really a strain on me & 0 & 1 & 2 & 3 & 4 & 5 & 6 \\
\hline 7 & I deal very effectively with the problems of other employees & 0 & 1 & 2 & 3 & 4 & 5 & 6 \\
\hline 8 & I feel burned out from work & 0 & 1 & 2 & 3 & 4 & 5 & 6 \\
\hline 9 & I feel I'm positively influencing other people's lives through this job & 0 & 1 & 2 & 3 & 4 & 5 & 6 \\
\hline 10 & I've become more callous toward people since I took this job & 0 & 1 & 2 & 3 & 4 & 5 & 6 \\
\hline 11 & I worry that this job is hardening me emotionally & 0 & 1 & 2 & 3 & 4 & 5 & 6 \\
\hline 12 & I feel very energetic & 0 & 1 & 2 & 3 & 4 & 5 & 6 \\
\hline 13 & I feel frustrated by my job & 0 & 1 & 2 & 3 & 4 & 5 & 6 \\
\hline 14 & I feel I'm working too hard on my job & 0 & 1 & 2 & 3 & 4 & 5 & 6 \\
\hline
\end{tabular}




\begin{tabular}{|c|l|l|l|l|l|l|l|l|}
\hline 15 & I don't really care what happens to some employees & 0 & 1 & 2 & 3 & 4 & 5 & 6 \\
\hline 16 & Working with people directly puts too much stress on me & 0 & 1 & 2 & 3 & 4 & 5 & 6 \\
\hline 17 & I can easily create a relaxed atmosphere with other employees & 0 & 1 & 2 & 3 & 4 & 5 & 6 \\
\hline 18 & I feel exhilarated after working closely with other employees & 0 & 1 & 2 & 3 & 4 & 5 & 6 \\
\hline 19 & I have accomplished many worthwhile things in this job & 0 & 1 & 2 & 3 & 4 & 5 & 6 \\
\hline 20 & I feel like I'm at the end of my rope & 0 & 1 & 2 & 3 & 4 & 5 & 6 \\
\hline 21 & In my work, I deal with emotional problems very calmly & 0 & 1 & 2 & 3 & 4 & 5 & 6 \\
\hline 22 & I feel other employees blame me for some of their problems & 0 & 1 & 2 & 3 & 4 & 5 & 6 \\
\hline
\end{tabular}

\section{Copyrights}

Copyright for this article is retained by the author(s), with first publication rights granted to the journal.

This is an open-access article distributed under the terms and conditions of the Creative Commons Attribution license (http://creativecommons.org/licenses/by/3.0/). 